\title{
Life Cycle Assessment to Highlight the Environmental Burdens of Early Potato Production
}

\author{
Giuseppe Timpanaro ${ }^{1}\left(\mathbb{D}\right.$, Ferdinando Branca ${ }^{1}\left(\mathbb{D}\right.$, Mariarita Cammarata ${ }^{1}$, Giacomo Falcone ${ }^{2, *}(\mathbb{C}$ \\ and Alessandro Scuderi $1, * \mathbb{B}$ \\ 1 Department of Agriculture, Food and Environment (Di3A), University of Catania, 95123 Catania, Italy; \\ giuseppe.timpanaro@unict.it (G.T.); fbranca@unict.it (F.B.); mariar.cammarata@gmail.com (M.C.) \\ 2 Department of Agriculture (AGRARIA), Mediterranean University of Reggio Calabria, \\ 89122 Reggio Calabria, Italy \\ * Correspondence: giacomo.falcone@unirc.it (G.F.); alessandro.scuderi@unict.it (A.S.)
}

check for updates

Citation: Timpanaro, G.; Branca, F.; Cammarata, M.; Falcone, G.; Scuderi, A. Life Cycle Assessment to Highlight the Environmental Burdens of Early Potato Production. Agronomy 2021, 11, 879. https://doi.org/10.3390/ agronomy11050879

Academic Editor: Thomas Nemecek

Received: 16 April 2021

Accepted: 27 April 2021

Published: 29 April 2021

Publisher's Note: MDPI stays neutral with regard to jurisdictional claims in published maps and institutional affiliations.

Copyright: (c) 2021 by the authors. Licensee MDPI, Basel, Switzerland. This article is an open access article distributed under the terms and conditions of the Creative Commons Attribution (CC BY) license (https:// creativecommons.org/licenses/by/ $4.0 /)$.

\begin{abstract}
Climate change, food security, and the protection of the planet's resources require the adoption of sustainable production models. Achieving sustainable development in the agri-food sector enables the creation of new opportunities for operators, guiding farmers towards more environmentally friendly practices and offering cost-effective results. Organic farming paradigms are promoted by the transformation of some harmful practices of conventional agriculture, such as the wide use of chemical products of synthesis, the deep workings that favor the erosive processes, the excessive use of nitrogenous fertilizers. There are still gaps in the knowledge of the real performance of some products that strongly support the local economic system of Sicily (Italy). The research aims to highlight the differences in environmental impact caused by the cultivation of organic early potatoes compared to the conventional regime and the same per $\mathrm{kg}$ of product obtained. To this end, the widely used methodology for comparing the environmental impacts of agricultural production systems is the Life Cycle Assessment, which allows us to highlight the phases in which environmental criticalities are most concentrated. An interesting agroecological picture of knowledge emerges, since organic farming is by definition an ecological model that supports the principles of the Green Deal, it often requires interventions to improve the yields obtained in order to achieve a positive result both in terms of cultivated surface and $\mathrm{kg}$ of product obtained.
\end{abstract}

Keywords: LCA; sustainable; organic; agriculture; economics; sicily

\section{Introduction}

The growing demand for food as a result of the growth rate of the world's population requires agriculture to satisfy the needs both in terms of quantity produced and protection of non-renewable resources to guarantee their use for future generations. A key challenge is to ensure food security in the context of anticipated climate change challenges for a global population expected to grow to nine billion or more people by 2050, while preserving a safe operating space for humanity by avoiding dangerous environmental changes [1,2]. The concept of sustainability and its faithful application to all types of production also play a fundamental role in mitigation of climate change. Sectors such as agriculture, horticulture, forestry, and aquaculture contribute significantly to climate change via land use changes, fertilizer, and pesticide usage, embedded and production energy usage [3]. Climate change, food security, biodiversity protection and sustainable use of resources are the cornerstones of the recent EU strategy "Farm to Fork Strategy-for a fair, healthy and environmentallyfriendly food system" [4]. The agri-food sector needs to take the sustainable path to create new opportunities for operators, guide farmers towards more environmentally friendly practices and at the same time ensure economically advantageous results. The research objective is to compare the environmental impacts generated by the early potato cultivation 
process in organic and conventional regime in the area of Syracuse (Sicily), where this crop is grown.

For the dissemination of cultivation models based on sustainability, some studies establish comparisons between agricultural production systems, whether they be conventional, organic, or biotechnological [5], while others compare the use of different fertilizers in the production of beets or wheat [6]. Other authors draw a parallel between organic production and the recognized methods used in the agricultural field, such as the "Good Agricultural Practices" (GAP) developed and defined by the FAO as "practices which concretely contribute to environmental, economic, and social sustainability of on-farm production resulting in safe and healthy food and non-food agricultural products" $[7,8]$. In this context, organic farming is considered the method for the creation of agroecological objectives and resilient environments in transition to agriculture [9] with a reduced impact on soil, water, climate, biodiversity, etc. [10]. However, literature shows that the sustainability of agricultural practices in both organic and conventional farming systems is an important concern; just because a farm is organic does not mean that it is sustainable [11]. The theoretical environmental advantage of organic farming can in fact be reduced compared to well-managed conventional agriculture applying principles of economic and environmental sustainability [12]. To this aim, numerous methods and techniques are available to identify the negative externalities produced during agricultural processes in order to achieve environmental sustainability [13]. The Life Cycle Assessment is the methodology widely used to compare the environmental impacts of agricultural production systems. LCA has been applied to agricultural systems, i.e., primary food production, in a variety of geographical regimes, aiming at improving their environmental performance [14]. Environmental Life Cycle Analysis (LCA) provides a comprehensive and objective method of analysis that allows alternative production systems to be compared and it identifies where major consumption of resources and emissions to the environment occur, so highlighting where improvements in techniques are most needed [15]. The literature on LCA often highlights how agricultural production is the weak point in the life cycle of food products [16], although environmental impacts tend to vary according to agro-ecological characteristics and farming systems, e.g., greenhouse vs. open field, organic vs. conventional, and cultivated under different agro-climatic conditions [17]. One of the limits of this methodology is not considering the impact on biodiversity and habitats, although the use of pesticides, herbicides, and other plant protection products modifies ecological balances, inducing instability phenomena in agroecosystems [18].

In order to compare different cultivation systems, it is often necessary to apply different modeling approaches according to the most appropriate functional unit, data availability, and interpretation for a correct comprehension of the multifunctionality of biological systems $[19,20]$.

Energy consumption and environmental burdens associated with the production of tomatoes, peppers, melons, and zucchini were analyzed with LCA in order to plan local policies, sustainable production, and consumption patterns to create a "knowledge base" for environmental assessment in an extended agricultural production area such as the Mediterranean [21]. LCA was also used to calculate the global warming potential of 38 pairs of organic and conventional herbaceous systems and products in Spain, concluding that organic management reduces crop emissions by 36-65\% [22].

With regard to the environmental sustainability of agricultural products from conventional and organic farming, LCA studies have shown wide variation in the resource efficiency of products from these systems [23]. This is also because the environmental performance of organic farming compared to conventional farming increases when the entire agro-ecosystem is managed holistically [24].

To complete this overview of the economic and environmental performance of horticulture in the open field, the focus is on early potatoes grown conventionally and organically, in an area where they contribute to local economic development. The (Solanum tuberosum L.) potato is one of the most popular edible plants in the world. This tuberous crop if important 
for human and animal nutrition and is cultivated under various climatic conditions [25]. Early potato peculiarities are linked to the precocity of the production cycle, which is also able to influence the profitability trend of farms as long as the product arrives on the market when prices are high and there is less competition with potatoes from other production areas $[26,27]$.

Since the characteristics of the product and its distribution system can be strongly conditioned by entrepreneurial choices upstream of the product life cycle, the aim of the work is to highlight the main differences between several agricultural models such as conventional and organic farming, measuring the environmental impact generated by the cultivation process, through the use of LCA. In this way the results of agricultural systems can also be used for policy making or strategic environmental planning of the territory. The study is organized as follows: Introduction; Materials and methods, the materials deals with the characterization of the study area and the experimental design, while the methods are represented by the Life Cycle Assessment for the evaluation of environmental impacts and the economic analysis of cultivation; Results, in environmental and economic terms; Discussions and Conclusions.

\section{Materials and Methods}

\subsection{Characterization of Study Areas}

The early potato sector is characterized by three fundamental elements: concentration of production in only three Italian regions (Sicily, Campania, and Puglia), importance of exports for the sector economy, and the good reputation of the Italian product stemming from the special organoleptic characteristics of the local early potato [28]. The region considered in the study is Sicily, more specifically the Province of Syracuse, thanks to its vocation for early potato cultivation. According to ISTAT (National Institute of Statistics) economic data, in Italy the area cultivated with early potatoes in 2020 amounted to 13.8 thousand ha, $50 \%$ of which was in Sicily (Table 1). Interest in this production is to be found in the high adaptability and rusticity of the cultivated species, in the soil and climate characteristics of the territory that make it possible to anticipate the ripening and marketing calendar, as well as in the growing market demand from Northern European countries [29].

Table 1. Early potato production in Italy, by main production areas (2020) $\left(^{*}\right)$.

\begin{tabular}{lccc}
\hline Territory & Surface ha & Total Production q & $\begin{array}{c}\text { Harvested } \\
\text { Production q }\end{array}$ \\
\hline ITALY & 13,849 & $3,318,424$ & $3,243,036$ \\
Sicily & 6910 & $1,495,350$ & $1,472,150$ \\
Siracusa & 5300 & $1,135,000$ & $1,135,000$ \\
\% Sicily/Italy & 49.9 & 45.1 & 45.4 \\
\% Siracusa/Italy & 38.3 & 34.2 & 35 \\
\% Siracusa/Sicily & 76.7 & 75.9 & 77.1 \\
\hline
\end{tabular}

(*) Our elaboration on ISTAT data.

National production amounted to over 3.3 million quintals for the year 2020, of which about 1.5 million quintals came from Sicily (45\%).

Syracuse accounts for 5.3 thousand hectares of early potatoes and a production of almost 1.4 million quintals, which places the province at the top of early potato cultivation in Sicily (77\% of investments and $76 \%$ of total production) and in Italy (38\% of areas and $34 \%$ of total production).

The importance of cultivation in Syracuse can be attributed to:

- favorable soil and climate conditions;

- dynamic market demand;

- limited presence of early potato production from other regions on national and international markets during the period of Sicilian production;

- $\quad$ excellent product quality, highly competitive; 
- introduction of relevant technical-scientific innovations (especially in terms of mechanization of cultivation operations, varietal availability, etc.);

- high levels of capital and labor productivity.

In Sicily, potatoes generated more than 114 million euros of production in 2019, equal to $11 \%$ of the GSP (Gross Saleable Production) of vegetables in the same region.

\subsection{Experimental Design}

The study is based on a comparison between early potatoes (Solanum tuberosum spp.) grown according to organic (POrg) and conventional (PConv) farming protocols, whose cultivation cycle begins with planting in the first ten days of October (in areas not subject to frost) until the end of February and with harvesting from March to June.

The area used for the experimental trials is Syracuse (Sicily, Italy), suited to the cultivation of the crop in question.

A detailed analysis of the early potato cultivation cycle in the reference area shows that the first step is the preliminary soil tillage. In the conventional cultivation method, it is represented by ploughing in August, followed by two harrowings in September and October, respectively. The organic method, on the other hand, is characterised by additional tillage, the false sowing, carried out in November using the harrow with the aim of controlling the emergence of weeds, given that herbicides are not used. It follows that, in the conventional method, tubers are sown in November, while on organic farms they are sown in December. In both cases the use of tubers from foreign countries, such as Netherlands and France, was found. Furthermore, conventional farms use treated tubers, while organic farms use certified organic seed or, in the absence of these, they use untreated seed with derogation certification issued by ENSE (the National Seed Authority). Another difference found between the two cultivation methods concerns the quantity of seeds used at the time of sowing. In the case of organic cultivation, a slight increase in the quantity sown of $3200 \mathrm{~kg} / \mathrm{ha}$ was found, compared to $3000 \mathrm{~kg} / \mathrm{ha}$ in conventional cultivation. The first fertilisation is carried out at the time of sowing; in the conventional method, mineral fertilisers containing N, $\mathrm{P}$, and $\mathrm{K}$ are used, while the other applications are carried out at the time of tillering, in January, and when the tuber grows in March. In this case, too, mineral fertilisers are used, which are applied by means of furrowing machines. The organic method, on the other hand, is characterised by the application of organic fertilisers, manure, at the time of sowing, in December, and subsequent applications during the tillering phase (January), and also during the potato growth phase (March and April). In the conventional method, herbicides are also applied to the crop during sowing and tillering in order to control weeds, which is not the case in the organic system as the use of synthetic products is not allowed by law. As far as crop protection against various pathogens is concerned, the conventional method uses Mancozeb in the emergence phase, i.e., in December, and subsequent applications involve the use of Fosetyl Aluminium and copper oxychloride during the ripening phase. Since the latter is allowed in organic farming, it is used to carry out a first treatment at emergence, a second during the tillering phase and three applications during the ripening phase. No substantial differences were found between the two cultivation methods with regard to irrigation, on average nine irrigations are carried out with a watering volume of $243 \mathrm{~m} 3$ per watering. At this point it is possible to analyse the harvesting phase, which in both cases is carried out using potato digging machines; what distinguishes the two cultivation methods at this stage is the crop yield. While in conventional cultivation it amounts to about 33 tons/ha, in organic cultivation it drops to about 23 tons/ha. Based only on this figure, we would be inclined to say that the conventional method is more profitable than the organic method, even if this is partly compensated by the $10 / 20 \%$ higher selling prices, but our aim is to show which of the two is more sustainable in terms of the environment and human health.

In order to define cultivation models and understand the differences in environmental and economic impacts between organic and conventional methods, the methodology of comparative analysis between homogeneous models was chosen [30]. 
The surveys were conducted through direct interviews using a questionnaire administered to 20 companies specialising in early potato production. The reporting period is January-June in 2019 and in 2020,50\% of the sample is represented by farms in conventional cultivation and $50 \%$ in organic cultivation. The farms examined in relation to soil, climate, and management characteristics were chosen within the same town, located in the same district, and conducted by entrepreneurial figures with the same qualification, in order to reduce endogenous and exogenous factors (entrepreneurial qualifications) able to influence the results.

However, the comparison between the two techniques is necessary to determine the most environmentally and functionally efficient cultivation system in pursuit of sustainable crop development.

\subsection{Life Cycle Assessment (LCA) and Methodological Choices}

In pursuit of the research objective, the internationally recognised Life Cycle Assessment, a "compilation and evaluation of the inputs, outputs and the environmental impacts of a product system throughout its life cycle" [30-32], has been used. LCA tools have been significantly improved during the past three decades in order to become more systematic and robust for identifying and quantifying potential environmental burdens and impacts of a product, process or an activity [33].

LCA can have practical applications, such as its use as a support tool for Environmental Food Product Declarations [34] or by developing alternative scenarios to establish pathways of environmental performance improvement [35].

LCA consists of four different and iterative steps defined by the ISO standards: goal and scope definition, inventory analysis, impact assessment, and interpretation [36].

As regards the definition of the goal and scope, the research analyses the main differences in terms of environmental impact of early potatoes grown organically and conventionally [37].

In the first step the definition of the Functional Unit, "the measurement unit to which all inputs and outputs data are related" [38], is of fundamental importance. In this case it is identified in one hectare of cultivated area and in one $\mathrm{kg}$ of early potato in order to assess aspects of the production process and the production itself, expressed as $\mathrm{kg}$ of product obtained.

The aim of the study is on the one hand to define the impact generated by the cultivation of early potatoes in the considered area and to provide sector operators with alternative intervention scenarios in order to make production more sustainable, on the other hand, the aim is to make consumers aware of how much impact $1 \mathrm{~kg}$ of early potatoes generates The use of one hectare of cultivated area as a functional unit may have limitations because it does not provide any information about production but focuses on its impact on the territory, for this reason the research includes the product obtained.

As regards the system boundary a study "from cradle to farm gate" (Figure 1) was carried out, in agreement with ISO 14040:2006 in fact an LCA study does not always cover the whole production process, but can be restricted to a part of it. 


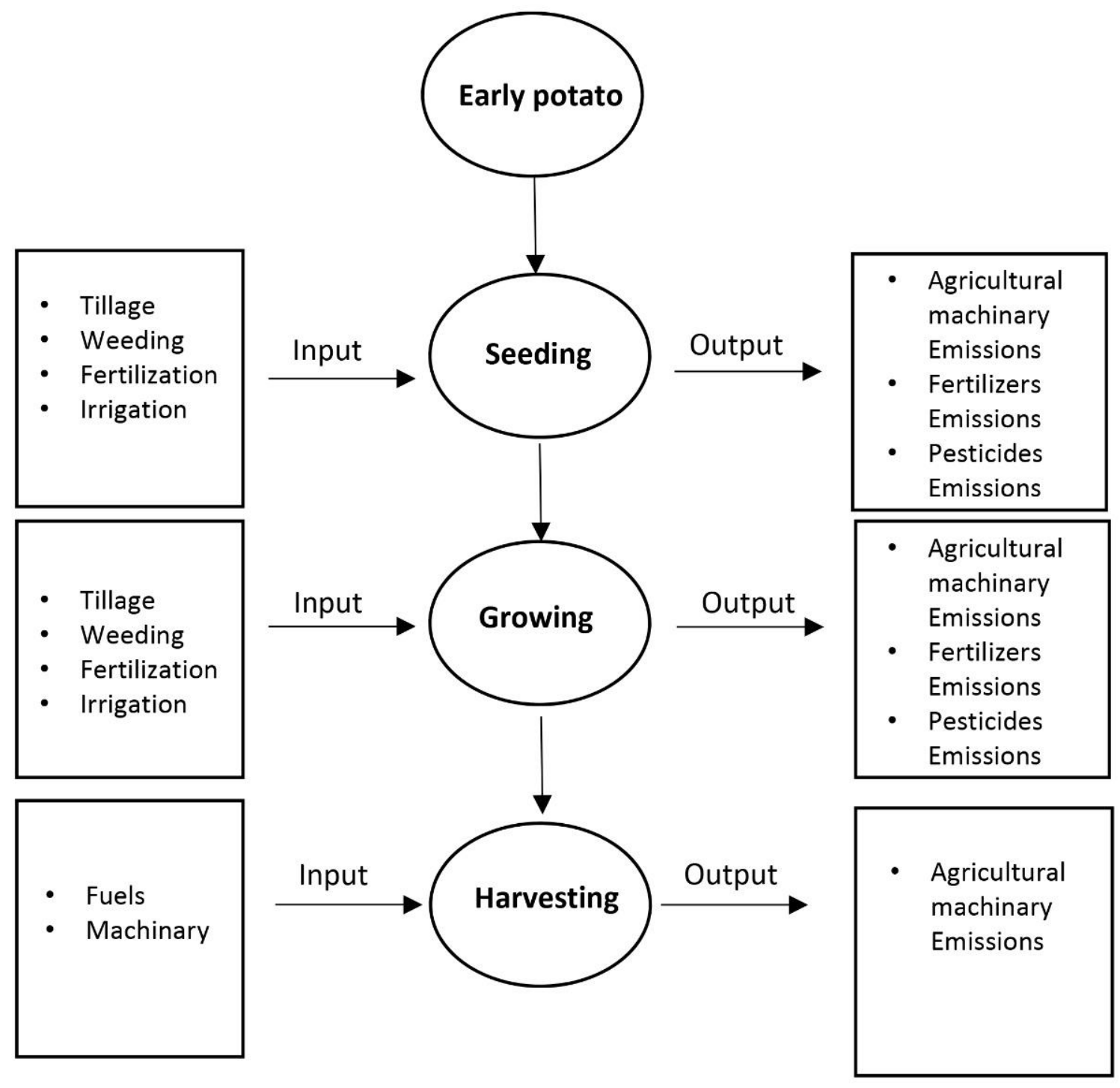

Figure 1. System boundary in the evaluation of LCA in early potatoes.

The choice was made both due to the difficulty of finding data relating to the packaging and distribution of the product, and to study the phases of the production process up to harvesting in order to evaluate the methods of land use.

Life Cycle Inventory

The second step concerns Life Cycle inventory analysis (LCI); this involves the collection of data defined by the materials and energy used in the system, emission to air, liquid effluents, and solid waste discharged into the environment [39].

During the study three types of data were used: primary data i.e., collected in the field through the use of a questionnaire relating to the entire production process of the potato from preliminary working to harvesting; secondary data, concerning the production phases of fuels, fertilisers and pesticides, have been obtained from Ecoinvent V 3.6 database, the most used Life Cycle Inventory dataset [40]; tertiary data, have been estimated in relation to emissions from the distribution of pesticides and fertilisers and diesel combustion [41]. All collected data for inventory analysis refers to the reference flow unit of 1 hectare (Table 2). 
Table 2. Inputs used in early potato cultivation in organic and conventional farming (unit data) $\left(^{*}\right)$.

\begin{tabular}{lccc}
\hline Input & Unit & Porg & Pconv \\
\hline Seeds & $\mathrm{kg} / \mathrm{ha}$ & 3200 & 3000 \\
\hline Fertilizer NPK (7-14-21) & $\mathrm{kg} / \mathrm{ha}$ & - & 1200 \\
\hline $\mathrm{N}$ & $\mathrm{g} / \mathrm{ha}$ & - & 84 \\
\hline $\mathrm{P}$ & $\mathrm{g} / \mathrm{ha}$ & - & 168 \\
\hline $\mathrm{K}$ & $\mathrm{g} / \mathrm{ha}$ & - & 252 \\
\hline Fertilizer N (26); SO3 & $\mathrm{kg} / \mathrm{ha}$ & - & 1200 \\
\hline $\mathrm{N}$ & $\mathrm{g} / \mathrm{ha}$ & - & 312 \\
\hline $\mathrm{SO3}$ & $\mathrm{g} / \mathrm{ha}$ & - & 390 \\
\hline Fertilizer N (13); K2O & $\mathrm{kg} / \mathrm{ha}$ & - & 1200 \\
\hline $\mathrm{N}$ & $\mathrm{g} / \mathrm{ha}$ & - & 156 \\
\hline K2O & $\mathrm{g} / \mathrm{ha}$ & - & 552 \\
\hline Organic Fertilizer (Manure) & $\mathrm{kg} / \mathrm{ha}$ & 3600 & - \\
\hline Herbicides (Glifosate; Metribuzion) & $\mathrm{g} / \mathrm{ha}$ & - & 3250 \\
\hline Pesticides (Mancozeb; Fosetil.Al; & $\mathrm{g} / \mathrm{ha}$ & - & 950 \\
\hline Copper oxychloride) & $\mathrm{g} / \mathrm{ha}$ & 1800 & - \\
\hline Organic Pesticides (Copper oxychloride) & $\mathrm{L} / \mathrm{ha}$ & 230 & 225 \\
\hline Diesel & $\mathrm{L} / \mathrm{ha}$ & $2,430,000$ & $2,430,000$ \\
\hline Water & & & \\
\hline (*) Our & & - & \\
\hline
\end{tabular}

$\left(^{*}\right)$ Our elaboration.

The cultivation period considered is eight months (from August to April) and this study refers to two cultivation cycles in the period 2018-2019 and 2019-2020.

Emissions from the use of agricultural machinery, as well as emissions from the distribution of fertilisers, were estimated using the suggestions of Nemecek and Kägi (2007). In particular, models were used to estimate emissions of nitrogen dioxide, nitrous oxide, ammonia, nitrates, and phosphorus run-off. [41]. For emissions calculation due to the use of pesticides, the Ecoinvent approach was used, in which "all pesticides applied for crop production were assumed to end up as emissions to the soil. The amounts of pesticides used as inputs were thus simultaneously calculated as outputs (emissions to agricultural soil). The substances specified in the inventories were used as references to correlate the corresponding emissions" [40]. In addition, no allocation process was carried out, so $100 \%$ of the emissions refer to 1 hectare of land invested in early potatoes and to $1 \mathrm{~kg}$ of early potatoes obtained.

The third step, LCIA "consists of quantifying potential environmental impacts, through the selection of impact categories and, for all of them, relevant indicators and characterization models" [40]. Life cycle impact assessment (LCIA) helps the interpretation of LCA studies by translating these emissions and resource extractions into a limited number of environmental impact scores [42]. Characterization factors at the midpoint level are located somewhere along the impact pathway, typically at the point after which the environmental mechanism is identical for all environmental flows assigned to that impact category [43]. This type of characterization is distinguished by a stronger relationship with environmental flows and a low level of uncertainty. In order to carry out the environmental impact assessment, the SimaPro 9.1. software was used, within which the Recipe midpoint method [44] was selected, one of the most used in the agricultural field thanks to the high number of indicators closely related to this topic.

The last step of the LCA refers to data interpretation in order to highlight the salient points of the product life cycle and define the most impacting phases in order to optimize the entire production process. 


\subsection{Economic Sustainability of Cultivation}

According to other methodologies adopted to enable analysis of farm income [45,46], the aim of this study was to evaluate the remuneration of employed capital and the ability of smallholders to compete in the global market and for this purpose the Economic Profit (Ep) has been used.

The Economic Profit takes into account not only intermediate consumption and depreciation but also costs for the remuneration of production factors (own and external). It corresponds to the amount remaining after remuneration of all production factors. Thus, farms can be compared irrespective of the family/non-family nature of the factors of production employed. Costs have been calculated on the basis of accounting information provided by farmers [29]. The methodologies used for the economic profit determination was the following:

$$
E p=[(O+P I+P I I+V A T)-(I C+F T+D)+S]-(T+W+R+F+L+C)]
$$

where: $E p=$ Economic profit; $S=$ subsidies on investment; $T=$ taxes on investment; $W=$ wages and social security charges; Rents = rent paid for farm land and buildings and rental charges; $F=$ Family labor costs; $L=$ costs of Own land costs; $C=$ costs of Own capital costs; $O=$ Output; $P I=$ Pillar I-type payments; $P I I=$ Pillar II-type payments; VAT balance; $I C=$ intermediate consumption; $F T=$ farm taxes; $D=$ depreciation.

Production costs were calculated by dividing them into three large categories, such as "materials", "labor and services", and "quotas and other attributes" (Table 3). The means of production and product area data were averaged over the two-year period 2018-2020, while the saleable produce prices refer to 2019/2020. Gross Saleable Product was determined from bulk sales where the purchaser arranges the harvesting, because this is the main means of sale practiced in the survey areas.

Table 3. Production cost categories.

\begin{tabular}{ll}
\hline Categories & Indicators \\
\hline Materials & Water; fertilizers; pesticides; herbicides; others \\
\hline \multirow{2}{*}{ Labour and services } & Farms works and mechanized services \\
& Mediation; Transport \\
& Professional consulting; Other \\
\hline \multirow{2}{*}{ Quotas and other attributes } & Quotas on land investments \\
& Quotas on stock investments \\
& Taxes and wages and social security charges \\
& Own capital cost \\
& Own land cost \\
\hline \multirow{2}{*}{ Output } & Products of the cultivation \\
\hline
\end{tabular}

\section{Results}

\subsection{Environmental Impacts of Conventional and Organic Farming}

Tables 4 and 5 show the results of the impact characterization for the two cultivation methods analyzed, the first refers to 1 hectare of early potatoes cultivation and the second to $1 \mathrm{~kg}$ of early potatoes. The characterization factors are grouped according to the protection areas on which they have a negative effect, therefore the first five impact categories together with Human carcinogenic toxicity and Human non-carcinogenic toxicity refer to the Human Health protection area, with the exception of the Global warming factor which is also classified in the Damage to ecosystem area due to its combined damage to human health and the environment. 
Table 4. Characterization factors and environmental impact per hectare in early organic and conventional potato cultivation $\left({ }^{*}\right)$.

\begin{tabular}{llcc}
\hline Impact Category & Unit & P Org & P Conv \\
\hline Global warming & $\mathrm{kg} \mathrm{CO} 2 \mathrm{eq}$ & 5013.522 & 9384.726 \\
Stratospheric ozone depletion & $\mathrm{kg} \mathrm{CFC11} \mathrm{eq}$ & 0.009 & 0.151 \\
Ionizing radiation & $\mathrm{kBq} \mathrm{Co-60} \mathrm{eq}$ & 178.192 & 186.667 \\
Ozone formation, Human health & $\mathrm{kg} \mathrm{NOx} \mathrm{eq}$ & 24.153 & 31.220 \\
Fine particulate matter formation & $\mathrm{kg} \mathrm{PM2.5} \mathrm{eq}$ & 16.939 & 19.376 \\
Ozone formation, Terrestrial ecosystems & $\mathrm{kg} \mathrm{NOx} \mathrm{eq}$ & 24.544 & 31.672 \\
Terrestrial acidification & $\mathrm{kg} \mathrm{SO}$ eq & 35.910 & 42.953 \\
Freshwater eutrophication & $\mathrm{kg} \mathrm{P} \mathrm{eq}$ & 1.549 & 1.834 \\
Marine eutrophication & $\mathrm{kg} \mathrm{N} \mathrm{eq}$ & 1.001 & 2.320 \\
Terrestrial ecotoxicity & $\mathrm{kg} \mathrm{1,4-DCB}$ & $53,371.950$ & $57,943.158$ \\
Freshwater ecotoxicity & $\mathrm{kg} 1,4-\mathrm{DCB}$ & 567.827 & 677.703 \\
Marine ecotoxicity & $\mathrm{kg} \mathrm{1,4-DCB}$ & 749.981 & 796.102 \\
Human carcinogenic toxicity & $\mathrm{kg} 1,4-\mathrm{DCB}$ & 203.251 & 202.291 \\
Human non-carcinogenic toxicity & $\mathrm{kg} 1,4-\mathrm{DCB}$ & $12,401.319$ & $13,581.233$ \\
Land use & $\mathrm{m} 2 \mathrm{a}$ crop eq & 743.930 & 673.793 \\
Mineral resource scarcity & $\mathrm{kg} \mathrm{Cu} \mathrm{eq}$ & 72.101 & 89.971 \\
Fossil resource scarcity & $\mathrm{kg}$ oil eq & 1459.176 & 1803.637 \\
Water consumption & $\mathrm{m} 3$ & 2483.224 & 2519.941 \\
\hline
\end{tabular}

$\left({ }^{*}\right)$ Our elaboration.

Table 5. Characterization factors and environmental impact per $\mathrm{kg}$ of early organic and conventional potatoes $\left(^{*}\right)$.

\begin{tabular}{llcc}
\hline Impact Category & Unit & P Org & P Conv \\
\hline Global warming & $\mathrm{kg} \mathrm{CO} 2 \mathrm{eq}$ & 0.2155815 & 0.2815418 \\
Stratospheric ozone depletion & $\mathrm{kg} \mathrm{CFC11} \mathrm{eq}$ & 0.0000004 & 0.0000045 \\
Ionizing radiation & $\mathrm{kBq}$ Co-60 eq & 0.0076623 & 0.0056000 \\
Ozone formation, Human health & $\mathrm{kg} \mathrm{NOx} \mathrm{eq}$ & 0.0010386 & 0.0009366 \\
Fine particulate matter formation & $\mathrm{kg} \mathrm{PM2.5} \mathrm{eq}$ & 0.0007284 & 0.0005813 \\
Ozone formation, Terrestrial ecosystems & $\mathrm{kg} \mathrm{NOx} \mathrm{eq}$ & 0.0010554 & 0.0009502 \\
Terrestrial acidification & $\mathrm{kg} \mathrm{SO}$ eq & 0.0015441 & 0.0012886 \\
Freshwater eutrophication & $\mathrm{kg} \mathrm{P} \mathrm{eq}$ & 0.0000666 & 0.0000550 \\
Marine eutrophication & $\mathrm{kg} \mathrm{N} \mathrm{eq}$ & 0.0000430 & 0.0000696 \\
Terrestrial ecotoxicity & $\mathrm{kg} \mathrm{1,4-DCB}$ & 2.2949938 & 1.7382948 \\
Freshwater ecotoxicity & $\mathrm{kg} \mathrm{1,4-DCB}$ & 0.0244166 & 0.0203311 \\
Marine ecotoxicity & $\mathrm{kg} 1,4-\mathrm{DCB}$ & 0.0322492 & 0.0238831 \\
Human carcinogenic toxicity & $\mathrm{kg} \mathrm{1,4-DCB}$ & 0.0087398 & 0.0060687 \\
Human non-carcinogenic toxicity & $\mathrm{kg} \mathrm{1,4-DCB}$ & 0.5332567 & 0.4074370 \\
Land use & $\mathrm{m} 2 \mathrm{a}$ crop eq & 0.0319890 & 0.0202138 \\
Mineral resource scarcity & $\mathrm{kg} \mathrm{Cu} \mathrm{eq}$ & 0.0031004 & 0.0026991 \\
Fossil resource scarcity & $\mathrm{kg}$ oil eq & 0.0627446 & 0.0541091 \\
Water consumption & $\mathrm{m} 3$ & 0.1067786 & 0.0755982 \\
\hline
\end{tabular}

$\left.{ }^{*}\right)$ Our elaboration.

Analyzing in detail the results obtained by the LCA per ha of cultivated surface, the "Global warming" indicator expressed in $\mathrm{kg} \mathrm{CO} 2$ eq shows a value equal to 5013.522 in the organic regime and 9384.726 for the conventional method, with an impact in the organic $47 \%$ less than conventional. This data shows a $47 \%$ reduction of the impact on the environment and human health in the organic regime compared to the conventional method, so it is easy to understand the advantages of applying the principles of organic farming to the early potato production process.

In the context of the "Stratospheric ozone depletion" whose unit of measurement is expressed in $\mathrm{kg} \mathrm{CFC11} \mathrm{eq,} \mathrm{the} \mathrm{organic} \mathrm{method} \mathrm{showed} \mathrm{a} \mathrm{value} \mathrm{of} 0.009$ compared to the conventional method, which instead is 0.151 , with a percentage reduction of $94 \%$ in organic method. The "Ionizing radiation" impact category, kBq Co-60 eq, has the following 
values for the organic and conventional methods respectively: 178.192 and 186.667 , with a reduced impact of $5 \%$ for the organic method.

Moving on to "Ozone formation", the values vary between 24.544 for organic and 31.220 for conventional, expressed in $\mathrm{kg}$ NOx eq, with a $23 \%$ reduction in organic, in this case also the conventional method reported higher impact values. For the "Fine particulate matter formation" category, values of 16.939 and 19.376, expressed in kg PM2.5 eq, were obtained for the organic and conventional methods, respectively. The first sees a reduction in impact compared to the conventional one of $13 \%$, which demonstrates the greater respect for human health by the organic method. Finally, the last impact categories belonging to this protection area are: "Human carcinogenic toxicity" and "Human noncarcinogenic toxicity", in which the organic sector produced the following results: 203.251 and 12401.319, while the conventional sector recorded 202.291 and 13581.233 in 1.4-DCB kg, respectively. In this case the percentage differences between the two cultivation methods amount to $0.5 \%$ less in conventional method for "Human carcinogenic toxicity" and 9\% less for organic in "Human non-carcinogenic toxicity" category. As regards the second protection area "Damage to Ecosystem", the values recorded are as follows: "Ozone formation, Terrestrial ecosystems", expressed in kg NOx eq, 24.153 for organic, and 31.672 for conventional. The percentage reduction of $23 \%$ for organic once again demonstrates the undisputed advantages of this method compared to the conventional one. In the case of the "Terrestrial acidification" indicator, 35.910 is the value recorded in organic farming and 42.953 is the value recorded in the case of conventional farming, both expressed in $\mathrm{kg}$ $\mathrm{SO} 2 \mathrm{eq}$, with a reduced impact of $16 \%$ for organic cultivation. Another important impact category considered is the "Freshwater eutrophication", whose unit of measurement is $\mathrm{kg} \mathrm{P}$ eq. It shows the following values respectively for organic and conventional: 1.549 and 1.834, where the impact reduction amounts to $16 \%$ for organic. For the category "Marine eutrophication", $\mathrm{kg} \mathrm{N}$ eq, the organic method reported a value of 1.001 while the conventional 2.320 with a reduced impact of $57 \%$ for organic. The data are also coherent in the case of the "Terrestrial ecotoxicity" indicator where organic is lower than conventional, respectively, with the following values: 53371.950 and 57943.158 both expressed in 1.4-DCB $\mathrm{kg}$. In this case the analysis shows a difference of $8 \%$. Within this protection area we find the impact category "Freshwater ecotoxicity", also expressed in 1.4-DCB kg, with a recorded value of 567.827 for the organic method and 677.703 for the conventional method, also in this category the impact of organic method is $16 \%$ lower than conventional one. In the case of the "Marine ecotoxicity" category (kg 1.4-DCB), the values are as follows: 749.981 for organic and 796.102 for conventional, with a $6 \%$ difference in favor of organic. Within the protection area in question it is possible to include the "Land use" category expressed in $\mathrm{m} 2 \mathrm{a}$ crop eq. In this an inversion of results can be observed, the organic method with a value equal to 743.930, has obtained a higher index than the conventional one with a value equal to 673.793 and therefore has a greater impact of $10 \%$. With regard to "Water consumption", expressed in $\mathrm{m} 3$, the results are not very distant in both cultivation methods respectively 2483.224 for organic and 2519.941 for conventional, also demonstrated by the reduction between the two values of $1 \%$ in favor of the organic method.

The "Damage to resource availability" protection area includes the categories Mineral resource scarcity and Fossil resource scarcity, expressed in kg oil eq and kg oil eq respectively. The first (Mineral resource scarcity) reported the following values: 72.101 for organic and 89.971 for conventional, with a reduced impact of $20 \%$ in organic cultivation; while the Fossil resource scarcity category has a value of 1459.176 for organic and 1803.637 for conventional, with an impact of $19 \%$ less in organic.

Figure 2 summarizes the two farming systems' results (Porg and Pconv) as a percentage of the average value of the impact category considered per hectar. 


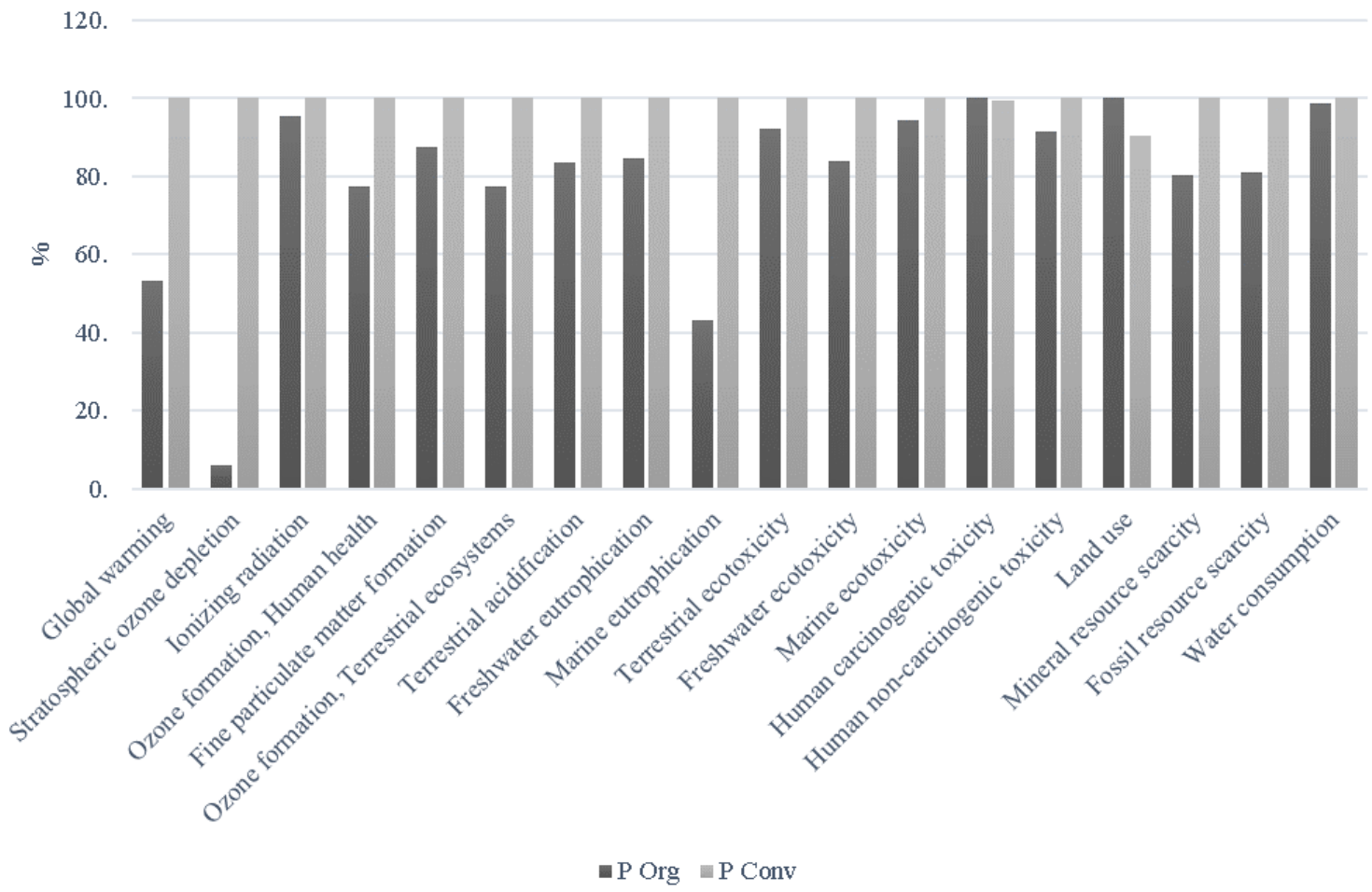

Figure 2. Impact comparison of organic and conventional production of the early potato (\% of average value for each category).

Table 5 shows the results per $\mathrm{kg}$ of early potatoes obtained in each impact category considered. In this case it is possible to observe a higher impact of the organic product than the conventional one in all impact categories with the exception of Global warming, in which the organic potato reported a $23 \%$ lower impact than the conventional one, Stratospheric ozone depletion with a reduction of $91 \%$ and Marine eutrophication with a lower impact of $38 \%$ than the conventional product. Concerning the other categories, it can be stated that for Ionizing radiation, organic has a 37\% higher impact than conventional, in Ozone formation Human health it has an increase of $11 \%$, rising to $25 \%$ in the category Fine particulate matter formation. For the following categories: Ozone formation Terrestrial ecosystems, Terrestrial acidification and Freshwater eutrophication organic early potato has a higher impact than conventional by $11 \%, 20 \%$, and $21 \%$, respectively. The categories Terrestrial ecotoxicity, Freshwater ecotoxicity, Marine ecotoxicity report a higher impact in the organic product of $32 \%, 20 \%$, and $35 \%$. As regards the categories Human carcinogenic toxicity and Human non-carcinogenic toxicity, the organic product is confirmed as having the greatest impact, with an increase compared to the conventional product of $44 \%$ and $31 \%$, respectively. The higher impact of conventional products is also confirmed in the last four categories shown in Table 5 where Land use shows an increase of $58 \%$. On the other hand, the categories Mineral resource scarcity, Fossil resource scarcity and Water consumption showed an increase in impact of $15 \%, 16 \%$, and $41 \%$, respectively, in the organic method. Figure 3 summarizes the two farming systems' results (Porg and Pconv) as a percentage of the average value of the impact category considered per $\mathrm{kg}$ of product obtained. 


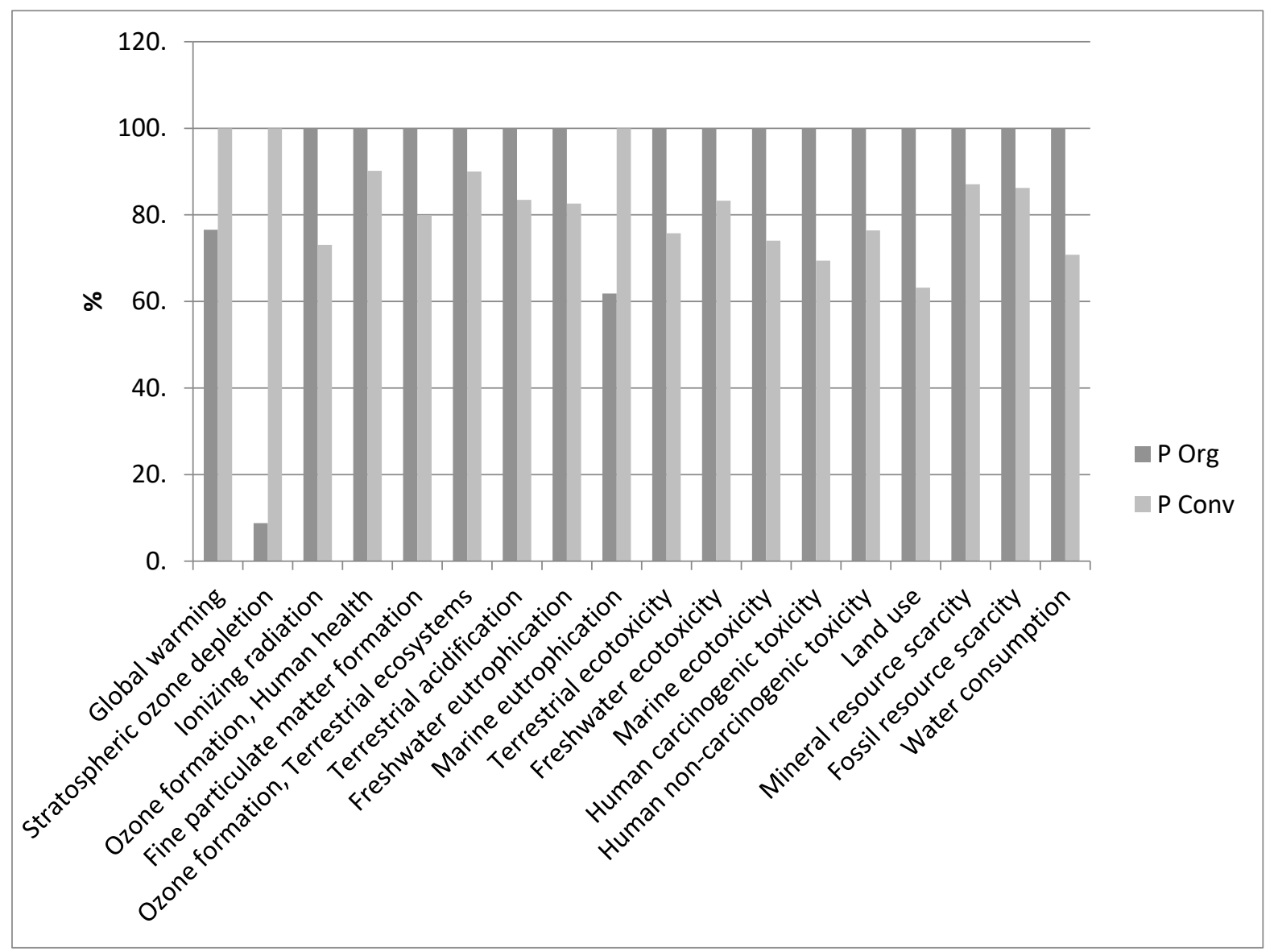

Figure 3. Impact comparison per $\mathrm{kg}$ of organic and conventional production of the early potato (\% of average value for each category).

\subsection{Economic Results in the Sample of Farms}

In order to determine production costs, it was necessary to calculate the various aspects of the farms' operations.

In particular, the level of activity (expressed in $\mathrm{h} / \mathrm{ha}$ ) on farms with organic and conventional early potato (Table 6) has a high degree of variability, although "extensification" processes facilitated by mechanical innovations in both production methods have been observed. In particular, for the cultivation of organic potatoes the average values are 400 , against $340 \mathrm{~h} / \mathrm{ha}$, with a greater workforce effort in organic farms of $60 \mathrm{~h} / \mathrm{ha}$. These differences are significant, if one takes into account that cultivation operations are mechanized, with the exception of manual weeding, which is essential for organic cultivation. As regards the other cultivation operations, the differences are not significant, with the exception of harvesting, carried out manually after digging the potatoes, resulting from a lower production per hectare of organic cultivation. Table 6 shows the differences for each operation carried out where it is possible to observe the comparison between the organic and the conventional method, which is considered the reference method. With regard to tillage, the percentage difference is $56 \%$ higher because, taking the conventional as a reference, the value indicates that the organic method requires a greater number of working hours than the conventional one; for sowing, the percentage difference is $4 \%$ higher in organic regime. Regarding fertilization, the hours spent in organic are reduced by $25 \%$ compared to conventional. For the pesticide treatments operation we can underline an increase of $80 \%$ in the hours spent on crop treatments in the organic regime compared to the conventional one. For the other operations listed in Table 6, such as irrigations, 
weeding, and harvest, the reduction in hours spent in the organic regime is $10 \%, 0 \%$, and $24 \%$, respectively.

Table 6. The activity level of early potato growing $\left(^{*}\right)$.

\begin{tabular}{lcc}
\hline Input & Conventional (a) & Organic (b) \\
\hline & h/ha & h/ha \\
\hline Tillage & 9 & 14 \\
Sowing & 27 & 28 \\
Fertilization & 4 & 3 \\
Pesticide treatment & 10 & 18 \\
Irrigations & 20 & 18 \\
Weeding & 0 & 115 \\
Harvest & 270 & 204 \\
Total & 340 & 400 \\
\hline
\end{tabular}

(*) Data collected through direct survey.

Overall, the average production costs for the two types of cultivation reach values of 10.9 thousand $€ /$ ha for organic and almost 9.6 thousand $€ /$ ha for conventional farms, with a $13 \%$ increase in costs (Table 7 ).

Table 7. Production costs of early potato growing $\left({ }^{*}\right)$.

\begin{tabular}{lll}
\hline Cost Category & Conventional (a) & Organic (b) \\
\hline Materials & $\mathbf{\ell} / \mathbf{h a}$ & $\mathbf{\ell} / \mathbf{h a}$ \\
Water & 4685.4 & 5282 \\
Seed & 469 & 411.7 \\
Fertilizers & 2931.1 & 3425.1 \\
Pesticides & 963.4 & 1249.8 \\
Others & 284.2 & 82.2 \\
Labour and services & 37.7 & 113.2 \\
Cultivation-related operations & 2320.3 & 3191.1 \\
Outsourcing service & 1667.5 & 2109.5 \\
Quotas and other attributes & 931.8 & 1081.6 \\
Administration, maintenance & 2653.4 & 2411.7 \\
Land assets interests & 694.3 & 823.4 \\
Intellectual labour & 594.21 & 677.3 \\
Taxes and other dues & 241.4 & 245.4 \\
Total average costs & 452.5 & 412.8 \\
\hline
\end{tabular}

(*) Data collected through direct survey. \%endtabular

For "materials", which have a greater impact on organic farming, average values of over 5.3 and 4.7 thousand $€$ /ha were observed respectively in the two production systems, attributable mainly to the purchase of seed tubers, fertilizers, and irrigation water. With reference to the category "labor and services", on average, the cost of labor in the conventional early potato sector accounts for almost 1.7 thousand $€ /$ ha depending on the various degrees of activity and the weight of manual labor; services amounting to 931.8 $€ /$ ha, on the other hand, are affected by mechanized operations and technical assistance.

Finally, the last cost category is represented by "quotas and other allocations", for which values of almost 2.6 thousand $€$ / ha were recorded in conventional cultivation, but decreased in organic cultivation by $9 \%$.

The analysis of farm sample revenues is shown in Table 8. Average yields vary from $25 \mathrm{t} /$ ha to $32 \mathrm{t} / \mathrm{ha}$ for organic and conventional farms, with a decrease of $22 \%$ for organic farms. This trend confirms that organic farming leads to a significant reduction in yields. 
Table 8. Economic values of early potato growing $\left({ }^{*}\right)$.

\begin{tabular}{lcc}
\hline & Conventional (a) & Organic (b) \\
\hline Indicators & & \\
Yield, $\mathrm{t} /$ ha & 32 & 25 \\
Sale prices, $€ /$ ha & 351 & 468.6 \\
Gross Production value $€ /$ ha & 11,232 & 11,715 \\
Production cost $€ /$ ha & 9659.1 & $10,884.8$ \\
Profits $€ /$ ha & 1572.9 & 830.2 \\
\hline
\end{tabular}

$\left.{ }^{*}\right)$ Data collected through direct survey.

The sales prices recorded an average price of $469 € / t$ and $351 € / t$ for organic and conventional products, respectively. The values obtained show a price decrease of $34 \%$ for organic products. The average value of gross production was 11.2 thousand $€ /$ ha considering the additional income from the EU payment (PSR 2014/2020), equal to $550 € /$ ha for organic farming and 11.2 thousand $€ /$ ha for conventional farming, with revenues above $4 \%$ for organic farms. Finally, examining the profits, there are lower values for organic farms, and higher values for conventional ones. The economic data show profits of 830.2 $€ /$ ha for organic farms and 1.6 thousand $€ /$ ha for conventional regime. Overall, the survey highlights the increased cost of organic farming, the low yields, and the corresponding marginal role of the high price of organic potatoes.

\section{Discussion}

The compared environmental impacts of the two cultivation methods have shown that the organic regime is more sustainable than the conventional one per ha of cultivated surface, instead per $\mathrm{kg}$ of product obtained there is an increased impact in organic early potatoes.

Regarding cultivation process in the impact categories belonging to the "Human Health" protection area, the results obtained are positive under the organic regime compared to the conventional one, the most impactful phases of the production process are sowing and the growing phase, both characterized by a wide use of mineral fertilizers, synthesis products, and emissions connected to the transport of the tubers from the place of purchase (Netherlands) to the utilization point. Particular attention should be placed on the "Stratospheric ozone depletion" category within which the large gap, also confirmed by the percentage difference between the two values, is attributable to the production phases of mineral fertilizers since the database used considers organic fertilizers with zero impact. The "Human carcinogenic toxicity" category registers a higher trend in organic farming compared to the conventional regime and this can be attributed to the growing phase where there is a large use of potassium sulphate during tuber growth, while for the impact category "Human non-carcinogenic toxicity" the results between organic and conventional do not differ much, however showing a lower impact for the organic method.

This is highlighted by Figures 4 and 5 in which the most impacting phases of the production process, sowing, and the growth phase are characterized by distribution of fertilizers and synthetic products. 


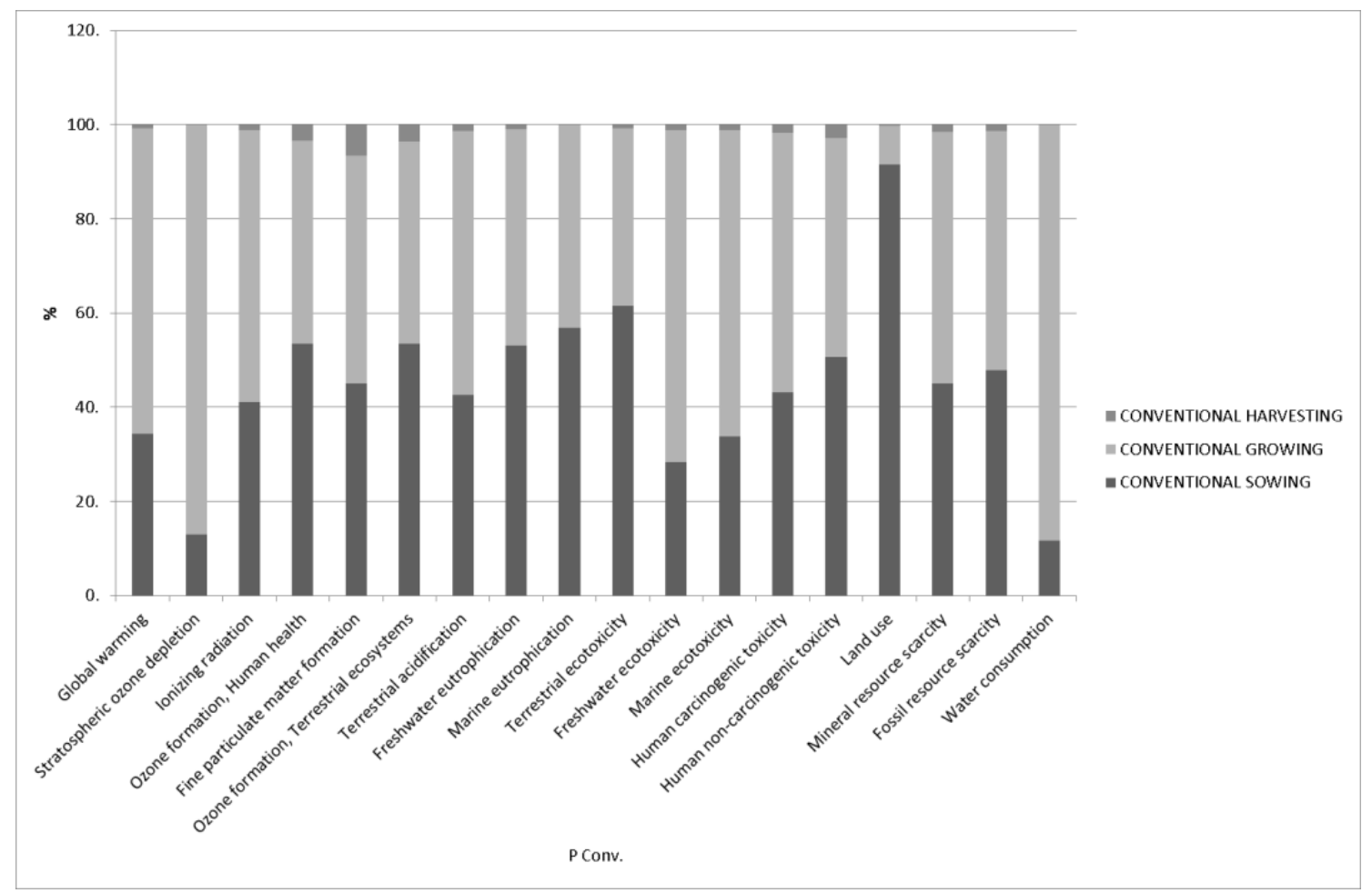

Figure 4. Environmental impact of early potato cultivation with conventional method, per impact category and main cultivation operations.

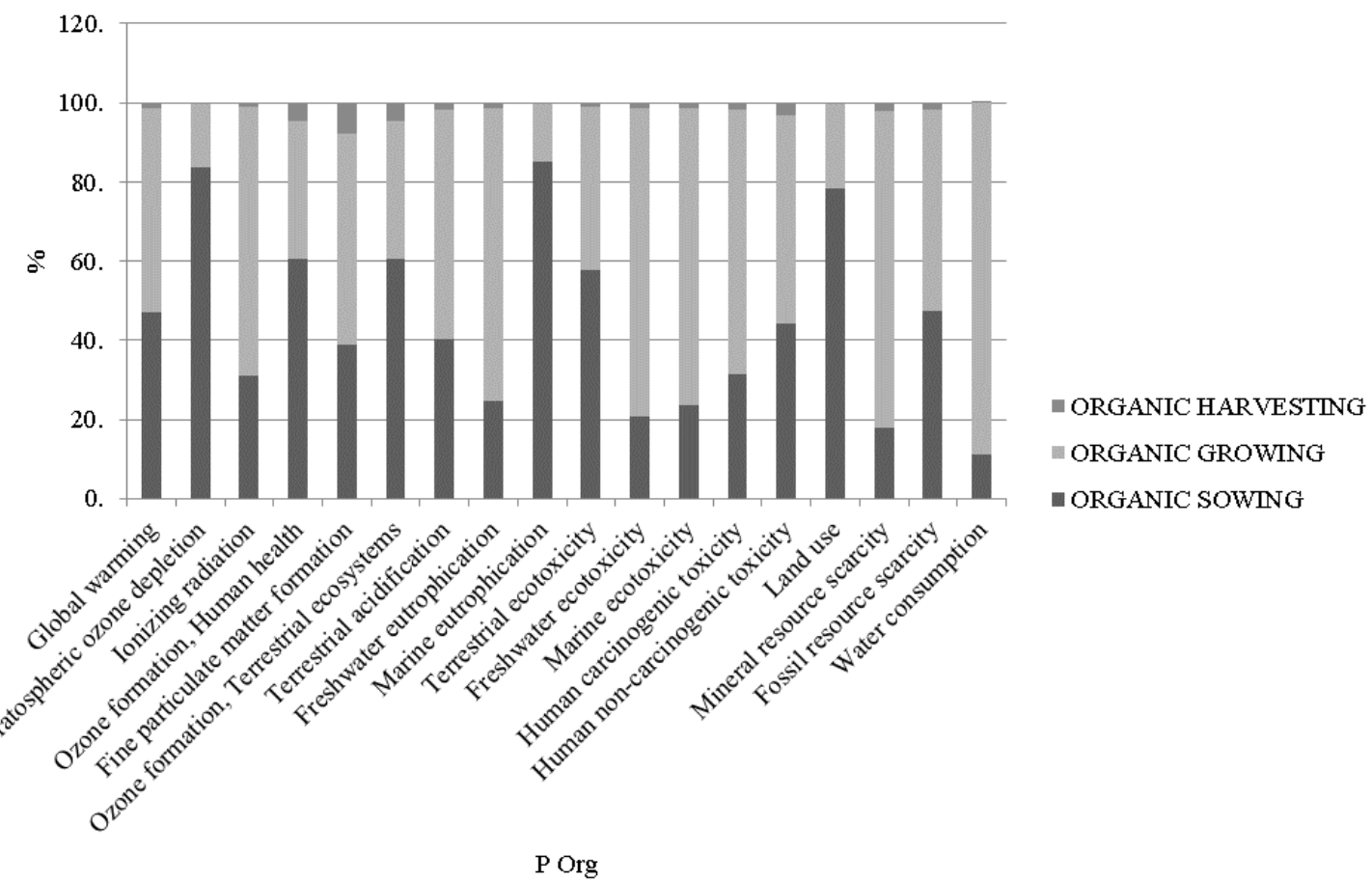

Figure 5. Environmental impact of early potato cultivation with organic method, per impact category and main cultivation operations.

In the case of the "Damage to Ecosystem" protection area, the results are more positive for organic farming, with the exception of the Land use category where the conventional regime has had a lower impact. This is essentially due to the greater number of processes 
carried out in organic farming to overcome the non-use of herbicides in the weed control. As for the previous protection area, also in this case the most critical phases of the whole production process are the sowing and the growing phase, which are characterized by a wide use of fertilizers and synthesis products. In line with previous results, for the Damage to resource availability protection area, the results obtained are decidedly positive in the organic area compared to the conventional regime, with the sowing and growth phase of the crop having a greater impact than the harvest. In relation to Fossil and Metal scarcity must be underlined the influence of machinery, diesel [47,48], and urea production [49].

Figures 6 and 7 show a detail of the main impact categories per $\mathrm{kg}$ of potatoes in both conventional and organic farming. In the conventional potato (Figure 6), within the Human Health category, the greatest impact is generated by the sowing and growing phase of the crop, when the greatest amount of synthetic fertilizers and plant protection products are applied, and consequently when there is the greatest fuel consumption due to the use of machinery. The same is true in all other impact categories except Land Use where the greatest impact occurs during the sowing phase due to the high number of mechanized operations for soil tillage and tuber sowing, and in Water Consumption where the greatest impact is during the growing phase where most irrigation is concentrated. In contrast to conventional potatoes, in organic potatoes the Human Health category has an impact generated more from the sowing phase as a result of more tillage (Figure 7). For the remaining categories, the impact is more attributable to the growing phase where, compared to conventional, a large amount of manure is applied and more fuel is consumed for machinery. The result remains unchanged for water consumption.

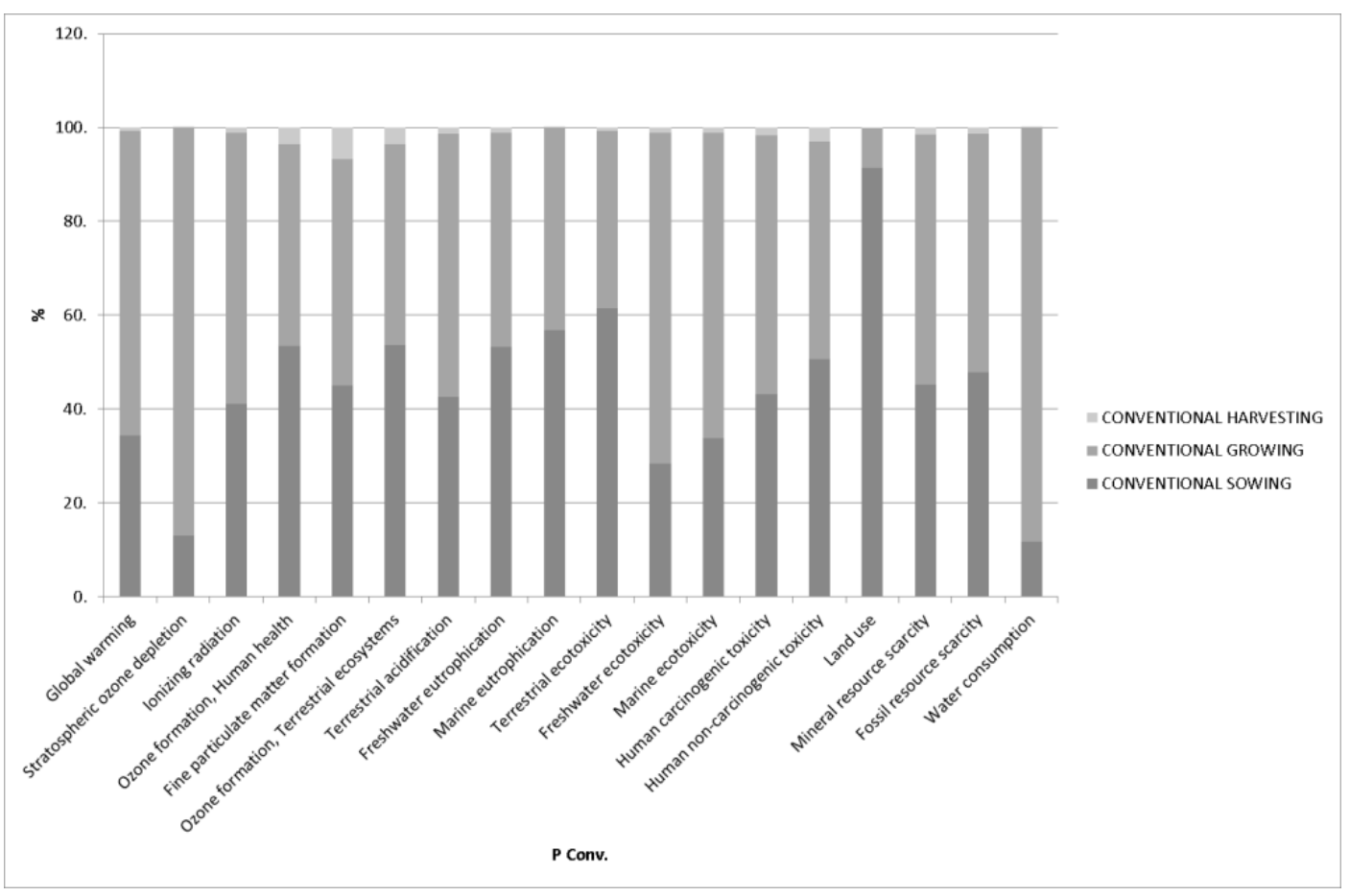

Figure 6. Environmental impact per kg of early potato with conventional method, per impact category and main cultivation operations. 


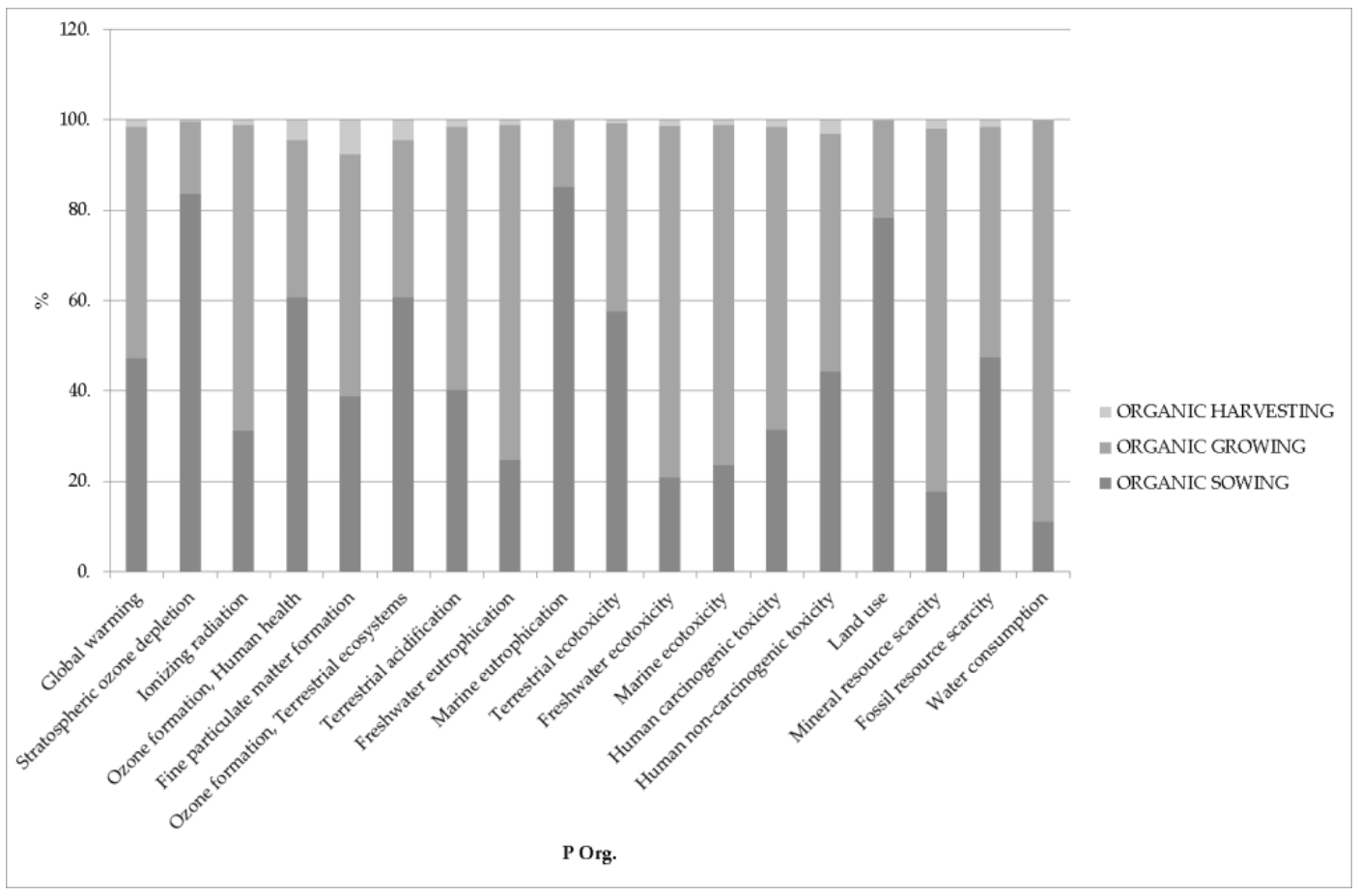

Figure 7. Environmental impact per $\mathrm{kg}$ of early potato cultivation with organic method, per impact category and main cultivation operations.

Considering other studies, such as Mattson and Wallen [50], in which the potato is analyzed using the LCA methodology, it is possible to find similarities with our study, although this is not an early potato (since it is typical of the area considered) and the system boundaries are different. As analyzed by the same authors, the $\mathrm{kg}$ of organic potato is characterized by a significant impact especially in terms of acidification and eutrophication that are not compensated by the yield of production, in fact our study shows that the conventional potato having a higher yield has a lower impact per $\mathrm{kg}$ of product obtained. Reduced average potato yields in organic farming leads to the use of more arable land [50], in addition, research and development of organic potato farming has been very limited so far. Potato yields would likely be increased by additional development work that would be environmentally beneficial [50].

According to Kowalczyk [25], sowing represents one of the principal hotspots of potatoes production as well as growing phase that account the impacts related to tillage operations, fertilization, and pest control. Even if a side-by-side comparison of results is not possible because of the different LCIA method used in our study, the contribution analysis shows a general overlapping of results obtained in [25], in which sowing represent on about $35 \%$, harvesting $15 \%$ and growing, as sum of tillage, fertilization, chemical plant protection and transports represent on average $50 \%$ of total impacts. Obviously, the comparison of contribution analyses must take into account the differences between a midpoint method which expresses impacts according to different categories and an endpoint method used to obtain a single impact score, therefore the result of normalization and weighting of characterization results.

In terms of economic impact, the early potato plays an important role for the sustenance of the territory both for the activities directly involved (in the agricultural phase) and for the induced activities (upstream and downstream phases, such as processing, marketing, etc.).

The two different types of product that can be obtained meet different fates in the markets. The early organic potato can meet quality enhancement strategies through the "EU Organic" label, in order to provide reassurance to the consumer and to help enterprises achieve a better performance on the markets. 


\section{Conclusions}

The research documents the study of the environmental impact of early potato production in Sicily, specifically in the Syracuse area. Thanks to the collaboration of the farmers, precise data were used which allowed an accurate assessment of the impact and consequently the definition of the major critical points found in the production process on which it is possible to intervene in order to achieve improvements. Therefore, on the basis of the results obtained it is possible to state that organic potato cultivation in the reference area is more sustainable than conventional cultivation. This is because in the organic regime the most delicate phases of the production process such as sowing and the growing are characterized by a lower use of synthesis inputs in terms of fertilizers and pesticides than in the conventional regime. On the other hand, the results per $\mathrm{kg}$ of product showed a higher impact in the organic method against a reduced yield compared to the conventional one.

Environmental sustainability is, in the case of early organic potato cultivation, also supported by economic sustainability, although profits were higher in conventional cultivation as a result of higher unit yields and consequent scale economies.

Organic farming must in fact be framed not only for the positive economic implications for the territory but also for the definition of possible development strategies at an individual and collective level extended to the product market.

Yield decreases have an important impact on LCA results, i.e., a reduction in losses would be beneficial to the environment [50], so the early potato obtained by organic production protocol should be the aggregating element for the organization of a supply chain system able to take this competitive advantage, which leverages on the organoleptic and nutritional characteristics of the product to ensure environmental, social, economic, and cultural sustainability to the whole territory.

The limitations found in the research mainly concern the conception that early potatoes are unfortunately still considered a niche product and the small size of the territory of analysis. The above points direct the research team's future work towards comparing organic and conventional early potato cultivation in different European countries.

Looking at a sustainable agriculture that follows the principles of the EU "Farm to Fork" strategy in order to obtain a positive or neutral environmental impact production and high levels of food security, it is necessary to safeguard the available resources and provide farmers with an overview of the environmental impacts generated by the production process. In this way, it is hoped that Sicilian potato farming will focus more on the improvement of organic yields in order to reduce the impact per $\mathrm{kg}$ of product obtained and combine this advantage with the positive results already achieved for cultivated surface.

Author Contributions: The paper is a collaboration of the authors. G.T., F.B., M.C., G.F. and A.S. all participated in the design, conceptualisation of the study design, review, editing, formal data analysis, validation and writing of the paper in equal measure. M.C. was also responsible for modelling the data on SIMAPRO. All authors have read and agreed to the published version of the manuscript.

Funding: PIAno di inCEntivi per la Ricerca di Ateneo (PIACERI) UNICT 2020/22 line 3 Starting Grant, University of Catania. Principal investigator Prof. Alessandro Scuderi.

Institutional Review Board Statement: Not applicable.

Informed Consent Statement: Not applicable.

Data Availability Statement: The data is not made public as it is digitally stored within the SimaPro software.

Conflicts of Interest: The authors declare no conflict of interest.

\section{References}

1. Sturiale, L.; Scuderi, A. The evaluation of green investments I urban areas: A proposal of an eco-social-green model of the city. Sustainability 2016, 10, 4541. [CrossRef]

2. Soussana, J.F. Research priorities for sustainable agri-food systems and lifecycle assessment. J. Clean. Prod. 2014, 73, 19-23. [CrossRef] 
3. Ingrao, C.; Matarazzo, A.; Tricase, C.; Clasadonte, M.T.; Huisingh, D. Life Cycle Assessment for highlighting environmental hotspots in Sicilian peach production systems. J. Clean. Prod. 2015, 92, 109-120. [CrossRef]

4. Eur-Lex. Communication from the Commission to the European Parliament, the Council, the European Economic and Social Committee and the Committee of the Regions a Farm to Fork Strategy for a Fair, Healthy and Environmentally-Friendly Food System. COM/2020/381 Final. Available online: https://eur-lex.europa.eu/legal-content/EN/TXT/?uri=CELEX:52020DC0381 (accessed on 19 November 2020).

5. Bennett, R.; Phipps, R.; Strange, A.; Grey, P. Environmental and human health impacts of growing genetically modified herbicidetolerant sugar beet: A life-cycle assessment. Plant Biotechnol. J. 2004, 2, 273-278. [CrossRef] [PubMed]

6. Brentrup, F.; Kusters, J.; Kuhlmann, H.; Lammel, J. Environmental impact assessment of agricultural production systems using the life cycle assessment methodology. I. Theoretical concept of a LCA method tailored to crop production. Eur. J. Agron. 2004, 20, 247-264. [CrossRef]

7. Comité de l'Agriculture. Élaboration D'un Cadre de Bonnes Pratiques Agricoles; FAO: Rome, Italy, 2003.

8. Basset-Mens, C.; Van Der Werf, H.M.G. Scenario-based environmental assessment of farming systems: The case of pig production in France agriculture. Ecosyst. Environ. 2005, 105, 127-144. [CrossRef]

9. Timpanaro, G.; Foti, V.T.; Spampinato, D. Organic Farming in Sicily: Analysis and perspectives through the main Productive Chains. Calitatea 2013, 14, 157.

10. Timpanaro, G.; Bellia, C.; Foti, V.T. Horticultural Agro-Biodiversity and Potential Conservation: Case Study in Sicily. Qual. Access Success 2014, 15, 230-235.

11. Nicolò, B.F.; De Salvo, M.C.; Ramirez-Sanz, C.; Estruch, V.; Sanjuan, N.; Falcone, G.; Strano, A. Life cycle assessment applied to different citrus farming systems in Spain and Italy. Agroecol. Sust. Food 2018, 42, 1092-1105. [CrossRef]

12. Tal, A. Making conventional agriculture environmentally friendly: Moving beyond the glorification of organic agriculture and the demonization of conventional agriculture. Sustainability 2018, 10, 1078. [CrossRef]

13. Falcone, G.; De Luca, A.; Stillitano, T.; Strano, A.; Romeo, G.; Gulisano, G. Assessment of Environmental and Economic Impacts of Vine-Growing Combining Life Cycle Assessment, Life Cycle Costing and Multicriterial Analysis. Sustainability 2016, 8, 793. [CrossRef]

14. Gulisano, G.; Strano, A.; De Luca, A.I.; Falcone, G.; Iofrida, N.; Stillitano, T. Evaluating the Environmental, Economic, and Social Sustainability of Agro-Food Systems Through Life Cycle Approaches. Sustain. Food Syst. Agric. Ind. 2018, 6, 123-152.

15. Williams, A.G.; Audsley, E.; Sandars, D.L. Energy and environmental burdens of organic and non-organic agriculture and horticulture. Asp. Appl. Biol. 2006, 79, 19-23.

16. Roy, P.; Nei, D.; Orikasa, T.; Xu, Q.; Okadome, H.; Nakamura, N.; Shiina, T. A review of life cycle assessment (LCA) on some food products. J. Food Eng. 2009, 90, 1-10. [CrossRef]

17. Parajuli, R.; Thoma, G.; Matlock, M.D. Environmental sustainability of fruit and vegetable production supply chains in the face of climate change: A review. Sci. Total Environ. 2019, 650, 2863-2879. [CrossRef]

18. Cerutti, A.K.; Beccaro, G.L.; Bosco, S.; De Luca, A.I.; Falcone, G.; Fiore, A.; Iofrida, N.; Lo Giudice, A.; Strano, A. Life-8-cycle assessment in the fruit sector. In Life Cycle Assessment in the Agri-Food Sector Case Studies. Methodological Issues and Best Practices; Notarnicola, B., Salomone, R., Petti, L., Renzulli, P.A., Roma, R., Cerutti, A.K., Eds.; Springer: Berlin/Heidelberg, Germany, 2015; Volume XXI.

19. Notarnicola, B.; Sala, S.; Anton, A.; McLaren, S.J.; Saouter, E.; Sonesson, U. The role of life cycle assessment in supporting sustainable agri-food systems: A review of the challenges. J. Clean. Prod. 2017, 140, 399-409. [CrossRef]

20. Sturiale, L.; Scuderi, A.; Timpanaro, G.; Matarazzo, B. Sustainable Use and Conservation of the Environmental Resources of the Etna Park (UNESCO Heritage): Evaluation Model Supporting Sustainable Local Development Strategies. Sustainability 2020, 12, 1453. [CrossRef]

21. Cellura, M.; Ardente, F.; Longo, S. From the LCA of food products to the environmental assessment of protected crops districts: A case-study in the south of Italy. J. Environ. Manag. 2012, 93, 194-208. [CrossRef] [PubMed]

22. Aguilera, E.; Guzmán, G.; Alonso, A. Greenhouse gas emissions from conventional and organic cropping systems in Spain. I. Herbaceous crops. Agron. Sustain. Dev. 2015, 35, 713-724. [CrossRef]

23. Meier, M.S.; Stoessel, F.; Jungbluth, N.; Juraske, R.; Schader, C.; Stolze, M. Environmental impacts of organic and conventional agricultural products-Are the differences captured by life cycle assessment? J. Environ. Manag. 2015, 149, 193-208. [CrossRef]

24. Schader, C.; Stolze, M.; Gattinger, A. Chapter 8 Environmental performance of organic farming. In Green Technologies in Food Production and Processing; Springer: New York, NY, USA, 2012; pp. 183-210.

25. Kowalczyk, Z. Life cycle assessment (LCA) of potato production. E3S Web Conf. 2019, 132, 02003. [CrossRef]

26. Butti Al Shamsi, K.; Guarnaccia, P.; Cosentino, S.L.; Leonardi, C.; Caruso, P.; Stella, G.; Timpanaro, G. Analysis of relationships and sustainability performance in organic agriculture in the United Arab Emirates and Sicily (Italy). Resources 2019, 8, 39. [CrossRef]

27. Timpanaro, G.; Scuderi, A.; Foti, V.T. A network for the conservation of agrobiodiversity of local ecotypes. VI Balk. Symp. Veg. Potatoes 2014, 1142, 163-170. [CrossRef]

28. Lombardi, P.; Caracciolo, F.; Cembalo, L.; Colantuoni, F.; D’Amico, M.; Del Giudice, T.; Maraglino, T.; Menna, C.; Panico, T.; Sannino, G.; et al. Country-of-Origin Labelling for teh Italian early potato supply chain. New Medit. 2013, 1, 37-48.

29. Scuderi, A.; Foti, V.T.; Timpanaro, G.; Sturiale, L. Economic and environmental analysis of organic early potatoes. Acta Hortic. 2016, 1142, 193-200. [CrossRef] 
30. Santucci, F.M. Limiti e necessità della comparazione tra biologico e convenzionale. In L'agricoltura Biologica in Italia—Metodologie di Analisi E Risultati Dell'utilizzo Dei dati RIC.; INEA: Brussels, Belgium, 2002.

31. International Organization for Standardization (ISO). 2006a ISO Norm14040:2006 Environmental Management-Life Cycle AssessmentPrinciples and Framework; ISO: Geneva, Switzerland, 2006.

32. International Organization for Standardization (ISO). 2006b ISO Norm14040:2006 Environmental Management-Life Cycle AssessmentPrinciples and Framework; ISO: Geneva, Switzerland, 2006.

33. Jeswani, H.K.; Azapagic, A.; Schepelmann, P.; Ritthoff, M. Options for broadening and deepening the LCA approaches. J. Clean. Prod. 2010, 12, 120-127. [CrossRef]

34. Schau, E.M.; Fet, A.M. LCA studies of food products as background for environmental product declarations. Int. J. LCA 2008, 13, e255-e264. [CrossRef]

35. Beccali, M.; Cellura, M.; Iudicello, M.; Mistretta, M. Life cycle assessment of Italian citrus-based products. Sensitivity analysis and improvement scenarios. J. Environ. Manag. 2010, 91, 1415-1428. [CrossRef]

36. De Luca, A.I.; Falcone, G.; Iofrida, N.; Stillitano, T.; Strano, A.; Gulisano, G. Life cycle methodologies to improve agri-food systems sustainability. Riv. Studi Sulla Sostenibilità 2015, 1, 135-150. [CrossRef]

37. Pergola, M.; D'Amico, M.; Celano, G.; Palese, A.M.; Scuderi, A.; Di Vita, G.; Pappalardo, G.; Inglese, P. Sustainability evaluation of Sicily's lemon and orange production: An energy, economic and environmental analysis. J. Environ. Manag. 2013, 128, 674-682. [CrossRef]

38. Bernardi, B.; Falcone, G.; Stillitano, T.; Benalia, S.; Bacenetti, J.; De Luca, A.I. Harvesting system sustainability in Mediterranean olive cultivation: Other principal cultivar. Sci. Total Environ. 2020, 766, 142508. [CrossRef] [PubMed]

39. Azapagic, A. Life cycle assessment as an environmental sustainability tool. Renew. Based Technol. 2006, 87-110. [CrossRef]

40. Falcone, G.; Stillitano, T.; Montemurro, F.; De Luca1, A.I.; Gulisano, G.; Strano, A. Environmental and economic assessment of sustainability in Mediterranean wheat production. Agron. Res. 2019, 17, 60-76.

41. Nemecek, T.; Kägi, T. Life Cycle Inventories of Agricultural Production Systems; Final Report Ecoinvent v2.0 No15 Swiss Centre for Life Cycle Inventories Dübendorf CH; Ecoinvent: Zurich, Switzerland, 2007; pp. 1-360.

42. Hauschild, M.Z.; Huijbregts, M.A.J. Life cycle impact assessment. In LCA Compend-Complet World Life Cycle Assess; Klöpffer, W., Curran, M., Eds.; Springer: Dordrecht, The Netherlands, 2015; Volume 3336, p. 339.

43. Goedkoop, M.; Heijungs, R.; Huijbregts, M.A.J.; De Schryver, A.; Struijs, J.; Van Zelm, R. ReCiPe 2008. In A Life Cycle Impact Assessment Method Which Comprises Harmonised Category Indicators at the Midpoint and the Endpoint Level, 1st ed.; Version 1.08; Report I: Characterisation; RIVM Report; RIVM: Bilthoven, The Netherlands, 2013.

44. ReCiPe. A Harmonized Life Cycle Impact Assessment Method at Midpoint and Endpoint Level Report I: Characterization; National Institute for Public Health and the Environment: Bilthoven, The Netherlands, 2016; pp. 1-194.

45. Blank, S.C.; Erickson, K.W.; Nehring, R.; Hallahan, C. Agricultural profits and farm household wealth: A farm-level analysis using Repeated Cross Sections. JAAE 2009, 41, 207-225. [CrossRef]

46. European Commission. Developments in the Income Situation of the EU Agricultural Sector, Directorate-General for Agriculture and Rural Development; European Commission: Brussels, Belgium, 2010.

47. Lovarelli, D.; Bacenetti, J. Bridging the gap between reliable data collection and the environmental impact for mechanised field operations. Biosyst. Eng. 2017, 160, 109-123. [CrossRef]

48. Lovarelli, D.; Bacenetti, J.; Fiala, M. Effect of local conditions and machinery characteristics on the environmental impacts of primary soil tillage. J. Clean. Prod. 2017, 140, 479-491. [CrossRef]

49. Bacenetti, J.; Lovarelli, D.; Fiala, M. Mechanisation of organic fertiliser spreading, choice of fertiliser and crop residue management as solutions for maize environmental impact mitigation. Eur. J. Agron. 2016, 79, 107-118. [CrossRef]

50. Mattsson, B.; Wallén, E. Environmental Life Cycle Assessment (LCA) of Organic Potatoes. Acta Hortic. 2003, 619, 427-435. [CrossRef] 